\title{
Correction to: Bias, dispersion, and accuracy of genomic predictions for feedlot and carcase traits in Australian Angus steers
}

Pâmela A. Alexandre1, Yutao Li ${ }^{1}$, Brad C. Hine², Christian J. Duff ${ }^{3}$ Aaron B. Ingham', Laercio R. Porto-Neto ${ }^{1}$ and Antonio Reverter ${ }^{1 *}$ (1)

\section{Correction to: Genet Sel Evol (2021) 53: 77} https://doi.org/10.1186/s12711-021-00673-8

After the publication of the original article [1], the authors noticed that there was an error.

In the first paragraph of page 5 , where we compare $\mathrm{ACC}_{\mathrm{LR}}$ and $\mathrm{ACC}_{\mathrm{T}}$, the accuracy symbols have been swapped. The right sentences are: "ACC $\mathbf{C}_{\mathrm{T}}$ were on average lower than $\mathbf{A C C}_{\mathbf{L R}}$ (Table 3) and more variable (Fig. 1b). This resulted in a much higher coefficient of variation for $\mathbf{A C C}_{\mathbf{T}}$ (Fig. 1c), particularly for ADG (41.06 vs. $7.79 \%$ ) and OSS (37.07 vs. 10.24\%)."

The related Table 3, Fig. 1 and the discussion around those results are correct.

\section{Reference \\ 1. Alexandre PA, Li Y, Hine BC, Duff CJ, Ingham AB, Porto-Neto LR, Reverter A. Bias dispersion and accuracy of genomic predictions for feedlot and car- case traits in Australian Angus steers. Genet Sel Evol. 2021;53:77. https:// doi.org/10.1186/s12711-021-00673-8.}

\section{Publisher's Note}

Springer Nature remains neutral with regard to jurisdictional claims in published maps and institutional affiliations.

\section{Author details}

${ }^{1} \mathrm{CSIRO}$, Agriculture and Food, Queensland Bioscience Precinct, 306 Carmody Rd., St Lucia, Brisbane, QLD 4067, Australia. ${ }^{2}$ CSIRO, Agriculture and Food, F.D. McMaster Laboratory, Chiswick, New England Highway, Armidale, NSW 2350, Australia. ${ }^{3}$ Angus Australia, 86 Glen Innes Rd., Armidale, NSW 2350, Australia.

Published online: 15 November 2021 permits use, sharing, adaptation, distribution and reproduction in any medium or format, as long as you give appropriate credit to the original author(s) and the source, provide a link to the Creative Commons licence, and indicate if changes were made. The images or other third party material in this article are included in the article's Creative Commons licence, unless indicated otherwise in a credit line to the material. If material is not included in the article's Creative Commons licence and your intended use is not permitted by statutory regulation or exceeds the permitted use, you will need to obtain permission directly from the copyright holder. To view a copy of this licence, visit http://creativecommons.org/licenses/by/4.0/. The Creative Commons Public Domain Dedication waiver (http://creativecommons.org/publicdomain/zero/1.0/) applies to the data made available in this article, unless otherwise stated in a credit line to the data. 